\title{
The Genetic Information Nondiscrimination Act of 2008
}

Carrie G. Donald, University of Louisville, USA

Adam K. Sanders, University of Louisville, USA

\begin{abstract}
This article argues that GINA theoretically protects people from genetic discrimination in insurance coverage and in employment; however, its true legacy will be assuring the American public that taking genetic tests will not invite sanctions from either insurance providers or employers.
\end{abstract}

\section{INTRODUCTION}

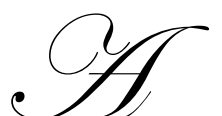

fter more than a decade of work and in one of the most significant scientific accomplishments in history, the Human Genome Project (HGP) announced in 2003 that it had mapped the entire human genome. ${ }^{1}$ Since the HGP started in the late 1980's, knowledge of human genetics has grown exponentially, enabling scientists and doctors to develop and provide genetic tests for over 1500 conditions currently. ${ }^{2}$ These breakthroughs have helped to identify diseases in individuals as well as to assist doctors decide the best form of treatment. ${ }^{3}$ As is often the case, the medical developments and breakthroughs occurred in advance of policy developments to ensure beneficial administration of the medical technologies or protection of individual rights. ${ }^{4}$ In the mid-1990's, some members of Congress became concerned about how some entities might use an individual's genetic information in the absence of laws designed to protect an individual from discrimination based on the individual's genetic information. Beginning in 1995, members of the House of Representatives and the Senate began to develop and to attempt to pass legislation that would have severely limited how employers and insurers could obtain and use genetic information. ${ }^{5}$ The effort to protect individuals from discrimination based on their genetic information culminated this year with the passage of the Genetic Information Nondiscrimination Act of 2008 (GINA), a bipartisan effort designed to prevent insurers from underwriting and employers from making employment decisions based on genetic information. ${ }^{6}$ Heralded by Senator Kennedy as "the first civil rights bill of the new century of the life sciences" $" 7$ the statute makes significant strides towards protecting individuals from discrimination based on their genetic information.

This article argues that GINA theoretically protects people from genetic discrimination in insurance coverage and in employment; however, its true legacy will be assuring the American public that taking genetic tests will not invite sanctions from either insurance providers or employers. Congress, aware of the imminent expansion of genetic technologies and applications has protected future generations of people whose medical care will involve ever increasing amounts of genetic information. ${ }^{8}$ Contrary to the arguments of a few critics, GINA effectively protects important privacy rights of people while avoiding burdening businesses with frivolous requirements. Beginning in Part II of this article, we offer a short history of the study of genetics as well as a history of the abuses of genetic sciences. Part III recounts the legislative history of attempts to pass genetic information nondiscrimination laws, including the history of GINA. Part IV comprehensively examines the statute's primary provisions relating to insurance and employment, evaluating criticisms of the statute. 


\section{GENETIC TECHNOLOGIES AND ISSUES}

\section{a. Technology}

According to several sources, the modern study of genetics began in 1953 when Francis Crick and James Watson discovered the double helix structure of deoxyribonucleic acid (DNA). ${ }^{9}$ Noting the potential for advancement in the field of genetics, in 1988 Congress funded the National Institutes of Health (NIH) and the Department of Energy (DOE) for a project to explore genes. ${ }^{10}$ The Human Genome Project officially started in 1990 and is now part of the National Human Genome Research Institute (NHGRI), a subsection of NIH. ${ }^{11}$ After several revisions of its timeline for completing mapping the entire human gene sequence, the HGP announced in April 2003 that it had successfully mapped the human genome, two years ahead of schedule. ${ }^{12}$ The HGP found around 20,500 different genes, while another scientist claims there might exist as many as 3.2 billion base pairs of DNA. ${ }^{13}$ Since all diseases have a genetic component, ${ }^{14}$ the mapping of the human genome could potentially affect methods of treatment and diagnosis for every disease.

The decoding of the human genome has been a monumental achievement in the treatment of many diseases. Genetic diseases tend to fall into one of three categories for the purposes of determining whether an individual will develop the disease or not. ${ }^{15}$ Monogentic conditions are those in which the existence or absence of the gene indicate to a certainty that an individual will develop a particular disease. ${ }^{16}$ Multifactoral conditions are those in which environmental factors play a much larger role. ${ }^{17}$ Usually, genetic tests of multifactoral cases will result in a "positive predictive value" (PPV) that estimates the individual's chances of developing the disease or disorder. ${ }^{18}$ Depending on factors other than genetics, the individual will or will not get the disease. ${ }^{19}$ The last type of conditions exists when an individual carries a gene which normally would cause a disease, but a "good" gene balances it out, rendering the gene harmless. ${ }^{20}$ However, the gene might be passed along to offspring, and if the "good" gene is not passed along with it, the offspring might develop the disease. ${ }^{21}$ Finding a gene or the absence of a gene, then, allows health professionals to predict the chances of an individual developing a particular disease. Predicting the existence of a disease allows a doctor to suggest lifestyle changes suited toward avoiding the manifestation of the disease. ${ }^{22}$ Diabetes, heart disease, Parkinson's disease, bipolar illness, and asthma are just a few of the diseases that genetic information has and will help to identify and treat. ${ }^{23}$

In addition to merely predicting possible future disease an individual may develop, the results of genetic testing sometimes offer doctors accurate predictors of which treatments will or will not be beneficial to treat a manifested disease. In addition, genetic knowledge may lead to the creation of genetically engineered organs for transplants. $^{24}$

\section{b. The Need For Protective Legislation}

While genetic sciences have offered spectacular advances in the medical field, the blemished societal record warns of the potential for current and future abuse. ${ }^{25}$ One of the first uses of the study of hereditary traits was to assign value to some traits and not to others. Those who held traits that society deemed "valuable" were encouraged to reproduce, while those with "poor" genes were discouraged. ${ }^{26}$ In many instances, this discouragement took the form of government-sponsored sterilizations.

Among the earliest influences of the eugenicist movement, albeit inadvertently, was Charles Darwin and his support of the "survival of the fittest" theory of evolution. ${ }^{27}$ As people began to apply this random theory (out of context) to human society, they claimed some traits as fit and some as non-fit. As one commentator notes, "[Darwin's] observations of nature...provided powerful groups with the assumed objectivity of science as a neutral justification for their supremacy over less popular and weaker segments of society." ${ }^{28}$ Hereditarians, later called eugenicists, began to discount the influence of one's environment on an individual's development, therefore believing, for instance, that an individual's propensity for becoming a murderer like his or her propensity to have blue eyes was based on traits passed down from parents. ${ }^{29}$ Unfortunately, as the eugenics movement gained momentum, the public saw lesser and lesser need for social reform based on rehabilitation, believing such reform to be nonproductive. ${ }^{30}$ 
Due to the prevalence of eugenicist views, the sterilization movement gained momentum, and with the help of government action. As a first step toward sterilization in 1896, Connecticut passed a law prohibiting "an epileptic, an imbecile or feebleminded" person to have certain sexual relations. ${ }^{31}$ In 1907, Indiana passed a statute requiring the sterilization of many criminals, idiots, imbeciles, and rapists, followed by similar laws in fourteen more states. ${ }^{32}$ In 1927, even the Supreme Court ruled that some sterilizations were constitutional as Justice Holmes sententiously opined, "three generations of imbeciles are enough.",33

Beginning in the 1920's, eugenicist views began fading due largely to three criticisms of the movement. The first was that eugenicists relied too heavily on hereditary factors for their health and behavioral determiners. ${ }^{34}$ Studies began to surface that demonstrated that even one with a propensity to develop a certain disorder, given environmental factors, may either never develop the disorder or may be able to treat it. ${ }^{35}$ Second, the scientific data compiled to support eugenicist theory lacked credible measurements and methodology, often basing conclusions on presumptions or on too little empirical evidence. ${ }^{36}$ The third primary criticism addressed the racist undertones of many of the eugenicist conclusions. ${ }^{37}$ As minority groups resisted the conclusions of eugenicists and as Americans witnessed the aftermath of the Nazi's Third Reich, many tried to distance themselves from eugenicist theories. ${ }^{38}$

Public fears about the use of genetic information result from much more recent abuses as well. In the 1970's, many employers began screening people for sickle cell anemia, a genetic disease afflicting AfricanAmericans. ${ }^{39}$ Unsubstantiated opinions of the time asserted that carriers of the disease, healthy individuals that tested positive for the sickle cell trait but showed no symptoms sickle cell anemia, would be more susceptible to certain hazards, including benzene, lead, carbon monoxide, and other chemicals. ${ }^{40}$ States began requiring screening for the disease in all African-Americans. ${ }^{41}$ When the confidentiality of these records was breached, even healthy carriers of the trait were burdened with a stigma. ${ }^{42}$ In addition, many were denied employment or health and life insurance do to their genetic diagnosis. ${ }^{43}$ Congress passed the National Sickle Cell Anemia Control Act in 1972, which instituted programs across the country to screen and treat people. ${ }^{44}$ The government conditioned its funding for the programs on the stipulation that the screening process was to be voluntary. ${ }^{45}$ In addition, any knowledge obtained through the programs was to be confidential. ${ }^{46}$ The sickle cell dilemma of the 1970's shared several traits with the eugenicist movement earlier in the century. Because the sickle cell trait was linked to race, any process singling out carriers of the disease was discrimination based on race. In addition, the discrimination against carriers of the sickle cell trait was based on poor scientific evidence. Studies did not support the proposition that carriers were more susceptible to environmental toxins. ${ }^{47}$

Up until the early 1990's, Lawrence Berkeley Laboratory tested its employees for sickle cell trait, syphilis, and pregnancy using urine and blood samples without the consent of the employees. ${ }^{48}$ In Norman-Bloodsaw v. Lawrence Berkeley Laboratory, the plaintiffs challenged the practice under the Americans with Disabilities Act (ADA), federal constitutional right to privacy, and Title VII of the Civil Rights Act of $1964 .{ }^{49}$ Although the plaintiffs failed on the ADA claim, they prevailed on the right to privacy issue because of the sensitive nature of medical information and the lack of consent. ${ }^{50}$ They also successfully argued the Title VII claim due to the race- and sex-based testing of potential employees as a condition of employment. ${ }^{51}$ While the court did recognize a constitutionally protected right to privacy, the court's holding is most likely limited. Since it was a constitutional issue, the holding only applies to government employees, so private employees would still be susceptible to discrimination of this sort. ${ }^{52}$ In addition, the testing was conducted without consent. ${ }^{53}$ Where an employee gives explicit or implicit consent, an employer could plausibly use genetic information for any purpose in the absence of legislation to protect the abuse of the information.

Another similar case occurred in Iowa when employees of the Burlington Northern Santa Fe Railroad complained that the railroad was administering genetic tests on employees who had carpel tunnel syndrome injuries. ${ }^{54}$ The employer either conducted the tests without the knowledge of the employees or asked the employees to consent to them. ${ }^{55}$ The Railroad was searching for a gene it believed sometimes caused carpel tunnel syndrome. ${ }^{56}$ The EEOC filed the complaint on behalf of the employees in February of 2001 basing their claim on the ADA. ${ }^{57}$ In May of 2002, the EEOC settled with the company in mediation agreements. ${ }^{58}$ The EEOC's position was that genetic testing was unlawful under the ADA because the testing did not relate to the job because the tests have no application to the present ability of an employee to perform a job. ${ }^{59}$ Presumably, the Railroad could have used the 
results of future tests to either fire employees with the undesirable gene or to place employees in different job placements because of the gene. ${ }^{60}$ In either case, the Railroad would have been using genetic information as a basis of discriminating against employees for a disease that had not manifested itself yet.

Employment practices raise special concerns. According to a study in 2002, one percent of employers were testing for Sickle Cell Anemia and .4 percent for Huntington's disease. ${ }^{61}$ Twenty percent of employers attempted to obtain medical histories. ${ }^{62}$ These statistics suggest that, while few cases of genetic discrimination exist, ${ }^{63}$ the potential for abuse is large and could continue to grow with the expansion of new technologies.

The nation's poor historical record of reckless and discriminatory abuses of personal genetic information lingers in the minds of the populace today. ${ }^{64}$ The eugenics movement discriminated against people on the basis of hereditary traits, often using science as an excuse for racism. Since eugenics has faded as a viable movement, genetic information has been used to discriminate against people in at least a few documented cases. Modern genetic science advances, with their ability to accurately map traits of an individual and link genes to certain diseases, increase the risk that entities will use genetic information for predictive value even when no disease is manifest. ${ }^{65}$ The work of the HGP has and will continue to greatly expand the predictive value of genetic information, making it valuable information for entities financially invested in an individual's future. Employers will often be interested in genetic information for the purposes of placing an employee, whether to hire an employee, to keep workers compensation costs down, or to attempt to predict employee future productivity ${ }^{66}$ Insurance providers will be interested for the purposes of setting premium and contribution rates and for determining an individual's eligibility for a plan. As Francis S. Collins explained, "Unless Americans are convinced that their genetic information will not be used against them, the era of personalized medicine may never come to pass.. ${ }^{, 67}$

Although some have claimed that they have been discriminated against by employers or insurers, the evidence is largely anecdotal. ${ }^{68}$ Even the Congressional Budget Office predicts that the GINA legislation will only impact six hundred people directly each year. ${ }^{69}$ However, much evidence exists that suggests the public remains cynical over how entities will use their genetic information once a health professional collects it. ${ }^{70}$ In a 2007 study conducted by the Genetics and Public Policy Center at John Hopkins University, a public opinion poll revealed 92\% of those in the study believed that genetic information gleaned from tests "could be used in ways that are harmful to the person." ${ }^{, 71}$ Very few of those respondents supported the use of genetic tests for the purposes of deciding insurance premiums or of making hiring and promotion employment decisions. ${ }^{72}$ However, an overwhelming majority support genetic testing for the purposes of diagnosing, preventing, or treating diseases. ${ }^{73}$ This discrepancy demonstrates that the public generally values genetic testing for the purposes of medical procedures and research, but not for insurance and employment decisions. ${ }^{74}$ The study concludes, "this enthusiasm about genetic testing [for health purposes] is tempered by widespread public concern and distrust about the discrimination that could result if insurers and employers access and use genetic test results." ${ }^{, 5}$ In addition, the Human Genome Project has recognized the potential for abuse resulting from the new technologies and has cited it as an area of great concern. ${ }^{76}$

While the purpose of GINA is certainly to protect individuals from discrimination, the law serves the broader purpose of attempting to eliminate fear that many may have of getting genetic tests administered. ${ }^{77}$ If the new law assures the public that their genetic information resulting from genetic tests will not be used to increase the cost of insurance, to deny eligibility for an insurance plan, or to determine job placement or other employment decisions, people will be much more likely to take advantage of the expanding science to help prevent, diagnose, and treat diseases, contributing to the nation's health. ${ }^{78}$ While few statistical studies suggest that many employers or insurance companies actually discriminate on the basis of genetic information, the public response to the potential for these abuses is clear. ${ }^{79}$ Laws protecting individuals from genetic discrimination will assure them that when they undergo genetic testing, employers and insurance companies will not use those results to discriminate against them.

In addition to popular opinion on the matter, traditional legal concepts indicate the government should legislate at least minimum safeguards protecting the use of a person's genetic information. An individual's genetic makeup shares similar vulnerabilities to discrimination as other categories that the Constitution and statutes currently protect. For instance, one's genetic makeup is immutable like gender and race. ${ }^{80}$ In addition, genetic discrimination results from a predisposition to a disease, not from the actual manifestation of disease. ${ }^{81}$ Similar to 
stereotypes of one's race or gender, discrimination because of genetics results from an assumption that might or might not be accurate, but an assumption that is nonetheless based on conjecture. ${ }^{82}$ This speculation, if not restrained, could subject many people who possess a specific genetic indicator to discrimination even though they will never develop the feared disorder or disease. ${ }^{83}$

\section{c. Current Legislation}

Congress has passed protective measures in the past that might cover some kinds of discrimination based on genetic information. Most applicable to genetic information are the Americans With Disabilities Act (ADA), the Health Insurance Portability and Accountability Act of 1996 (HIPAA), and the Social Security Act (SSA) ${ }^{84}$

The ADA offers partial protection against genetic discrimination because it attempts to prevent discrimination directed at a person with a disability or at a person who seems to have a disability. ${ }^{85}$ In the context of employment, the ADA covers private employers who employ fifteen or more employees ${ }^{86}$ However, many critics have pointed out its shortcomings. For instance, the ADA only protects against an employer abusing genetic information, but does not prevent the employer from acquiring this information. ${ }^{87}$ Enforcement of the use of genetic information is logistically much more difficult than limiting the acquisition of these materials. An employer, whether hiring or firing, might base a decision on genetic information while purporting to have some other more legitimate motivation. Preventing employers from accessing this information in the first place minimizes the chances that it will be used for discriminatory purposes. ${ }^{88}$

The ADA might also apply in the insurance context but the Supreme Court has not yet addressed whether the act prohibits discrimination based on genetic information for the purposes of eligibility and premiums for insurance programs. ${ }^{89}$ Although the ADA affords some protection in the employment context, the possibility exists that it will not apply to insurance companies for underwriting purposes. ${ }^{90}$

HIPAA does provide some protections against abuse for the insured or those seeking to be insured. Although the application is only to group health plans (not individual health plans), it protects against an insurer raising the cost of premiums or denying coverage to an individual based his or her genetic information. ${ }^{91}$ In addition, HIPAA protects individuals by requiring that insurance companies not treat genetic information as preexisting conditions until a disorder or disease manifests itself. ${ }^{92}$ However, even under HIPAA, a group insurer is allowed to increase rates for the entire group based on the genetic information of an individual or individuals. ${ }^{93}$ The act does not protect subscribers to individual health plans, only group plans, nor does it apply to large employers. ${ }^{94}$ Nor does HIPAA prohibit insurers from requiring subscribers to take genetic tests or from disclosing genetic information. ${ }^{95} \mathrm{In}$ summary, while HIPAA protects individuals from rate increases if they are in a group plan based on genetic information, it does not prevent using this information to increase the collective rate of the group, to assess premium rates and eligibility of individuals under group plans sponsored by large employers, or to assess premium rates and eligibility of individuals in individual health plans.

HIPAA also protects the confidentiality of certain types of medical information and the Health and Human Services regulation provide adequate protection for many types of information. ${ }^{96}$ However, these regulations are limited by the organic statute that allows regulations only as they apply to providers, payers, and information clearinghouses, not to any other category. ${ }^{97}$ Any entities besides those in the three listed categories, then, are not statutorily required to protect genetic information. ${ }^{98}$

Under SSA, the Employee Retirement Income Security Act (ERISA) governs supplemental insurance polices, or Medigap policies. ${ }^{99}$ Individuals on certain Medicare plans can purchase Medigap plans to cover some of the gaps in the Medicare insurance. ${ }^{100}$ Under ERISA, the Medigap policies cannot discriminate against an applicant in premiums or eligibility for most any health related reason, including general health status. ${ }^{101}$ No court so far has addressed whether or not genetic information falls into this category, ${ }^{102}$ but given the broad language, it probably does. This most likely insures that those who want or have Medigap policies will not face discrimination related to those policies based on their genetic information. 


\section{HISTORY OF THE CURRENT LEGISLATION}

Congressional consideration of provisions to protect the way entities used genetic information began in the mid-1990s. In 1995, Representative Slaughter introduced the Genetic Information Nondiscrimination in Health Insurance Act of $1995 .{ }^{103}$ In the next year, the same Congress passed HIPAA, another provisions addressing the misuse of medical information protecting against the "discrimination against an individual in a group based on health status, including genetic information.," ${ }^{04}$ In the 105th, 106th, and 107th Congresses, Representative Slaughter again introduced genetic information nondiscrimination bills addressing discrimination in employment context or the insurance industry or both. ${ }^{105}$ In 2003 in the 108th Congress, Slaughter introduced a similar bill again, and this time it was referred to committees, and the Subcommittee on Employer-Employee Relations held a hearing examining the affect of the proposed bill on the workplace. ${ }^{106}$ Around the same time, Senator Snowe introduced comparable legislation in the Senate, which was approved by a vote of 95 to 0 , but the House took no action. ${ }^{107}$ Representative Biggert introduced the Genetic Information Nondiscrimination Act of 2005 in the 109th, but again the body took no action. ${ }^{108}$ In that same Congress, the Senate passed Senator Snowe's version of the bill with a vote of 98 to 0 but the House held it at the desk. ${ }^{109}$

Finally, in January of 2007, Slaughter introduced a bill into the House of Representatives to protect genetic information that would become law. ${ }^{110}$ The Genetic Information Nondiscrimination Act of 2007 is virtually the same bill that ended up passing both houses of Congress, with minor changes. ${ }^{111}$ During the 110 th Congress, the bill was referred to several committees and subcommittees. ${ }^{112}$ The House of Representatives passed the bill on April 25, 2007 with a vote of 420 to $3 .{ }^{113}$ Senator Snowe introduced a similar bill, although with notable differences, in the Senate in the same Congress. ${ }^{114}$ The Senate passed a slightly different version of the House bill on April 24, 2008 with a unanimous vote, and then the House agreed to the Senate amendment on May 1, 2008 with a vote of 414 to $1 .^{115}$ President Bush signed the act into law on May 21, 2008. ${ }^{116}$

\section{PROVISIONS OF GINA}

GINA is divided into three different titles. The first addresses the use of genetic information in the health care industry. The second proscribes certain uses and requests for genetic information by employers. The final title contains miscellaneous provisions, the most substantive of which provide harsher penalties for violations of child labor laws. Introducing the legislation is an extensive preamble that outlines the progress made in medical technologies due to the expansion of genetic knowledge, the history of genetic discrimination in the country, the close relationship between genetic discrimination and racial discrimination, and the current need for protections for genetic information.

\section{a. Title I: Genetic Information And Health Insurance}

Title I amends ERISA, the Public Health Services Act, the Internal Revenue Code of 1986, and the SSA. Among these various amendments, GINA applies to insurers of both group and individual plans, filling many of the gaps left by previous legislation. Generally, the statute prohibits issuers of both group plans and individual plans from using genetic information to set or adjust premium or contribution rates. ${ }^{117}$ For group plans, this means that insurers, while they currently may not adjust the rates of an individual in a group plan based on genetic information, ${ }^{118}$ now may not adjust the rates for groups based on the genetic information of an individual in that group. ${ }^{119}$ In addition, while ERISA already prohibited the use of genetic information in the determination of eligibility for group plans, ${ }^{120}$ GINA extends this protection to individual plans and to Medicare supplemental plans under Medigap. ${ }^{121}$ In sum, GINA fully protects individuals in group plans and individual plans from an issuer of a policy using genetic information either to set premium or contribution rates or to determine eligibility for a plan.

The protections extend even further. GINA also has provisions to prevent insurers from getting genetic information about enrollees or potential enrollees. Subject to an exception, issuers of policies shall not "request or require an individual or a family member of such individual to undergo a genetic test." 122 The only exception to this provision is when an insurer, for the purpose of research, may request (but not require) a participant to take a genetic test. ${ }^{123}$ When conducting this research, the issuer of the policy must inform the participant that the test is voluntary 
and that the results will not affect premiums or eligibility, the issuer must notify the Secretary about the request for tests, and the issuer must comply with any other requirements the Secretary might mandate. ${ }^{124}$ Issuers likewise are prohibited from any attempts to obtain genetic information for the purposes of setting premium or contribution rates or of determining eligibility. ${ }^{125}$ However, issuers of policies are permitted to obtain genetic information for other purposes. ${ }^{126}$ While the provision most likely attempts to protect an insurer from the incidental collection of genetic information, it allows collection of this information as long as the collection was not for the purposes of underwriting. ${ }^{127}$ GINA protects potential enrollees in a similar way by prohibiting the collection of genetic information prior to enrollment if the collection is "in connection with such enrollment." 128

The title broadly defines "genetic information" to include information obtained through genetic tests of an individual or of an individual's family members, as well as information of a manifested disease in an individual's family member. ${ }^{129}$ This broad definition prohibits an insurer from using the disease of a family member as a consideration in setting premium rates or in determining eligibility. Furthermore, the act extends to protect the genetic information of fetuses and of legally possessed embryos. ${ }^{130}$

Section 105 extends HIPAA privacy protections to genetic information. This provision classifies genetic information as "health information," which is already subject to protection under HIPAA. ${ }^{131}$

The penalties for noncompliance differ depending on which department oversees the entity in violation for either group plans or individual plans. ${ }^{132}$ Generally, GINA allows the Secretary of the department to impose a penalty against a violating entity of one hundred dollars a day per person during which the entity is in violation. ${ }^{133}$ The minimum penalty is $\$ 2,500$, unless the violation or violations result in more than de minimis injury, in which case the minimum fine shall be $\$ 15,000 .{ }^{134}$ In addition to secretarial enforcement, GINA offers individuals a private right of action because of the act's incorporation into existing statutes. ${ }^{135}$ Violations of the privacy provisions will be in accord with Title I of HIPAA. ${ }^{136}$ Since the statute was enacted on May 21, 2008, all the provisions of Title I shall take effect on May 21, 2009. ${ }^{137}$

Critics of the insurance provisions of GINA argue that instead of encouraging people to undertake genetic testing, Title I will actually discourage the testing. ${ }^{138}$ Because an insurance company is now unable to request or require an enrollee to take a genetic test, an enrollee might not take a test the results of which might prevent further illness. ${ }^{139}$ Instead of encouraging genetic testing in an effort to promote health, these critics argue that the unintended consequences serve the opposite purpose. However, the research, as noted above, indicates that a majority of Americans already fear taking genetic tests because of how insurers or employers might use that information. While the provisions of Title I may inadvertently discourage a few people from taking genetic tests, many others will take these tests under the assurance that insurers will not use the information to increase their premiums or to disqualify them from coverage.

\section{b. Title II: Genetic Information And Employment}

Title II of GINA generally prevents employers, employment agencies, joint labor-management committees, and labor agencies from discriminating against employees or members based on genetic information. ${ }^{140}$ Using the same definitions as in the Civil Rights Act of 1964, "employer" defines an entity that employs at least fifteen employees. ${ }^{141}$ "Genetic information" consists of the same information as GINA denotes in Title I: information from genetic tests, information from the genetic tests of family members, and information about the manifestation of a disease in family members. ${ }^{142}$ Also as in Title I, manifested diseases or disorders in an individual do not constitute genetic information. ${ }^{143}$ In addition, Title II of GINA also considers a request for genetic services as genetic information in itself, so that a covered entity may not discriminate against an employee or member due to a request for these services. ${ }^{144}$

For employers, Title II prohibits making choices to hire, discharge, or discriminate against "any employee with respect to the compensation, terms, conditions, or privileges of employment" because of genetic information; nor shall an employee, because of genetic information of employees, classify or segregate them in a way that would limit their employment opportunities. ${ }^{145}$ Much like Title I with the issuers of insurance, Title II attempts to prevent 
the employer from accessing the information at all. The statute prohibits employers from requesting, requiring, or purchasing genetic information about an employee. ${ }^{146}$ However, because of the nature of the employer-employee relationship, Congress wrote in several exceptions to an employer's acquisition of genetic information. An employer may acquire this information when the information is obtained through an employer-provided wellness program, but only if the employee signs a written agreement voluntarily and with knowledge of his or her rights, and if individually identifiable information remains undisclosed. ${ }^{147}$ An employer may also obtain genetic information if in order to comply with state medical leave provisions or the Family and Medical Leave Act of $1993 .{ }^{148}$ Employers can access an employee's genetic information if the information is in any publicly available document, and can access the information if the employer is conducting DNA analysis for forensic law enforcement purposes. ${ }^{149}$ If an employer must monitor the effects of toxic substances in the workplace on the health of employees using genetic information, the employer may obtain the information only when the employer provides written notice to the employee, the employee voluntarily submits to the testing or the testing is required by law, the employee receives the monitoring results of the test, the employer does not receive personally identifiable information about individual employees, and the monitoring is in compliance with genetic monitoring regulations. ${ }^{150}$ Most importantly, Congress recognized that employment relationships do not exist in a vacuum. The "water-cooler" exception allows an employer to obtain genetic information of an employee inadvertently. ${ }^{151}$ An employer, because of this exception, will not be held responsible for an employee, for instance, discussing an illness in the family with the employer.

The prohibitions for employment agencies, labor organizations, and training programs are similar to those for employers. Employment agencies are prohibited from using genetic information to attempt to get an employer to discriminate against an employee. ${ }^{152}$ Labor organizations are prohibited from excluding or expelling from membership because of genetic information, and like employment agencies, may not attempt to get an employer to discriminate against someone because of the information. ${ }^{153}$ In addition, each of these entities (employer, employment agency, and labor organization) is prohibited from discriminating against a member or employee based on genetic information in training program opportunities. ${ }^{154}$

Title II also protects the privacy of genetic information. GINA treats genetic information in an employee's file as a "confidential medical record" as defined in the ADA, requiring that medical information be kept in a file separate from the general personnel files. ${ }^{155}$ This genetic information may only be disclosed under certain circumstances. An employee or member may issue a written request for the information. ${ }^{156} \mathrm{~A}$ health researcher may access these records pursuant to Federal regulations. ${ }^{157}$ If a court orders the disclosure of the information, the employer or labor organization may release only as much information as is ordered, and must notify the employee or member of the information disclosed. ${ }^{158}$ Employers may also release the information for an investigation of a claim under GINA, for proof of an employee's compliance with family and medical leave laws, and for a health agency investigating a contagious disease, but for this last the employer may only release information about a manifested disease in a family member of an employee. ${ }^{159}$

Enforcement of Title II is described in section 207. The enforcement regime for employers is the same as it is under Title IV of the Civil Rights Act of $1964 .{ }^{160}$ An employee must file with the Equal Employment Opportunity Commission (EEOC) before filing with a court and will be entitled to the remedies available under 42 U.S.C. $\S$ 1981a. ${ }^{161}$ However, some variation exists among the remedies depending on how the certain employer is classified. ${ }^{162}$ Section 208 excludes disparate impact as a cause of action for the purposes of GINA, although the act directs a commission to explore the possibility of incorporating this cause of action six years after the enactment of the act. Title II will take effect eighteen months after the enactment of the bill: November 21, 2009. ${ }^{163}$

Some critics have voiced concern over Title II of GINA. First, many are worried that GINA creates a new cause of action against employers that might result either in frivolous lawsuits or employer liability for only minor infractions. ${ }^{164}$ Under GINA, an employee might have a cause of action if an employer files papers incorrectly even absent any actual discrimination. ${ }^{165}$ While this is plausibly true, it is no more a danger than under ADA. Because recordkeeping requirements mimic the requirements of other confidential documents, GINA makes the transition as easy as possible for the employer. Other critics complain that since GINA only preempts less restrictive state laws while more restrictive state laws are still enforceable, the Federal legislation creates an unworkable "patchwork" of laws across the country, compliance with which will be difficult for national insurance companies and employers. ${ }^{166}$ 
However, before GINA existed, the patchwork was even more extensive. GINA preempts all state laws that are less restrictive. This inevitably creates a more uniform system. Had GINA attempted to preempt all state genetic discrimination laws, it would lower the standards in many states. Since both Title I and Title II of GINA adapt to already existing legislation, issuers of insurance and employers already have systems in place for compliance.

\section{CONCLUSION}

GINA might have significant effects on insurers and employers, but Congress did well to balance the competing concerns of genetic discrimination and administrative burdens. Insurers, while few discriminate based on genetic information currently, might have, in the future, used advanced technologies to fit genetic profiles into actuarial tables. Since GINA now will preclude insurers from doing so, the insurance industry may lack data that it believes will make insurance coverage more efficient. Some argue that since insurance companies may use other indicators, such as a manifested disease, to determine premiums and eligibility, they should be permitted to use genetic information. However, the determination that genetic information is different from other types of information is not random. The close relationship between genetic information and race, for instance, makes clear the fears about abuse of the information. Furthermore, the history of abuse of such information forebodes similar mistakes in the future.

GINA also leverages a burden on employers. Employers must now keep confidential certain information that before they did not. Such information might include something as seemingly innocuous as information about relatives of an employee. Harmless errors might subject an employer to lawsuits. While this in itself is a burden, it differs little from the ADA requirements already in place. The restrictions ensure that employers will not make decisions based on a prediction of the future that may or may not be accurate.

\footnotetext{
${ }^{1}$ H.R. Rpt. 110-28 Part 1 at 27 (March 5, 2007); Jennifer S. Geetter, Coding for Change: The Power of the Human Genome to Transform the American Health Insurance System, 28 Am. J.L. \& Med. 1, 1-2 (2002).

${ }^{2}$ Hudson, Kathy L., et al., Keeping Pace with the Times - The Genetic Information Nondiscrimination Act of 2008, 358 The New England J. of Med. 2661, 2661 (June 19, 2008).

${ }^{3}$ Christine Formas Norris, The Genetic Information Nondiscrimination Act of 2008: History, Successes, and Future

Considerations, 7 U. Md. J. Race, Gender, \& Class 192, 194 (2007).

${ }^{4}$ The benefits of many fast-developing technologies might be jeopardized by the lack of regulations.

${ }^{5}$ Rep. Slaughter introduced the first legislation dealing explicitly with genetic information in 1995. H.R. 2748, 104th Cong. (1995). See also H.R. Rpt. 110-28 Part 1 at 23 (March 5, 2007).

${ }^{6}$ Pub. L. No. 110-223.

${ }^{7} 154$ Cong Rec S 3363.

${ }^{8}$ Collins indicates that within the next few years, the cost of mapping an individual's entire genome will be around $\$ 1000$. Doctors will be able to use this information continuously for diagnosis, treatment, and preventative courses of action. Francis Collins, Testimony before the H.R. Subcommittee on Health: Committee on Energy and Commerce (March 8, 2007).

${ }^{9}$ National Human Genome Research Institute, An Overview of the Human Genome Project, http://www.genome.gov/12011239 (last updated May 6, 2008).

${ }^{10} I d$.

${ }^{11}$ National Human Genome Research Institute, About the National Human Genome Research Institute, http://www.genome.gov/10001167 (last updated November 2006).

${ }^{12}$ Congressional Research Service (CRS) Report for Congress, Genetic Information: Legal Issues Relating to Discrimination and Privacy, (updated March 10, 2008), 1.

${ }^{13}$ National Human Genome Research Institute, An Overview of the Human Genome Project, http://www.genome.gov/12011238 (last updated May 9, 2008); Patrinos, Aristides. "The Human Genome Project: What Minorities Need to Know." From the proceedings of the conference The Challenges and Impact of Human Genome Research for Minority Communities, July 7-8, 2000, put on by Zeta Phi Beta Sorority, Inc.; CRS, supra n. 12, at 1.

${ }^{14}$ CRS, supra n. 12 , at 2.

${ }^{15}$ This article focuses on only one small area related to genetics - the value of the science for predicting future diseases in individuals. Congress enacted GINA primarily for this reason. Representative Slaughter, who introduced the bill into the House of Representatives, said, "GINA prohibits group health plans and health insurers from denying coverage to a healthy individual or charging that person higher premiums based solely on a genetic predisposition to develop a disease in the future. Furthermore, it bars employers from using an individual's genetic information when making hiring, firing, job placement or promotion decisions.” H.R. Rpt. 110-28 Part 3 at 64 (March 29, 2007).
} 


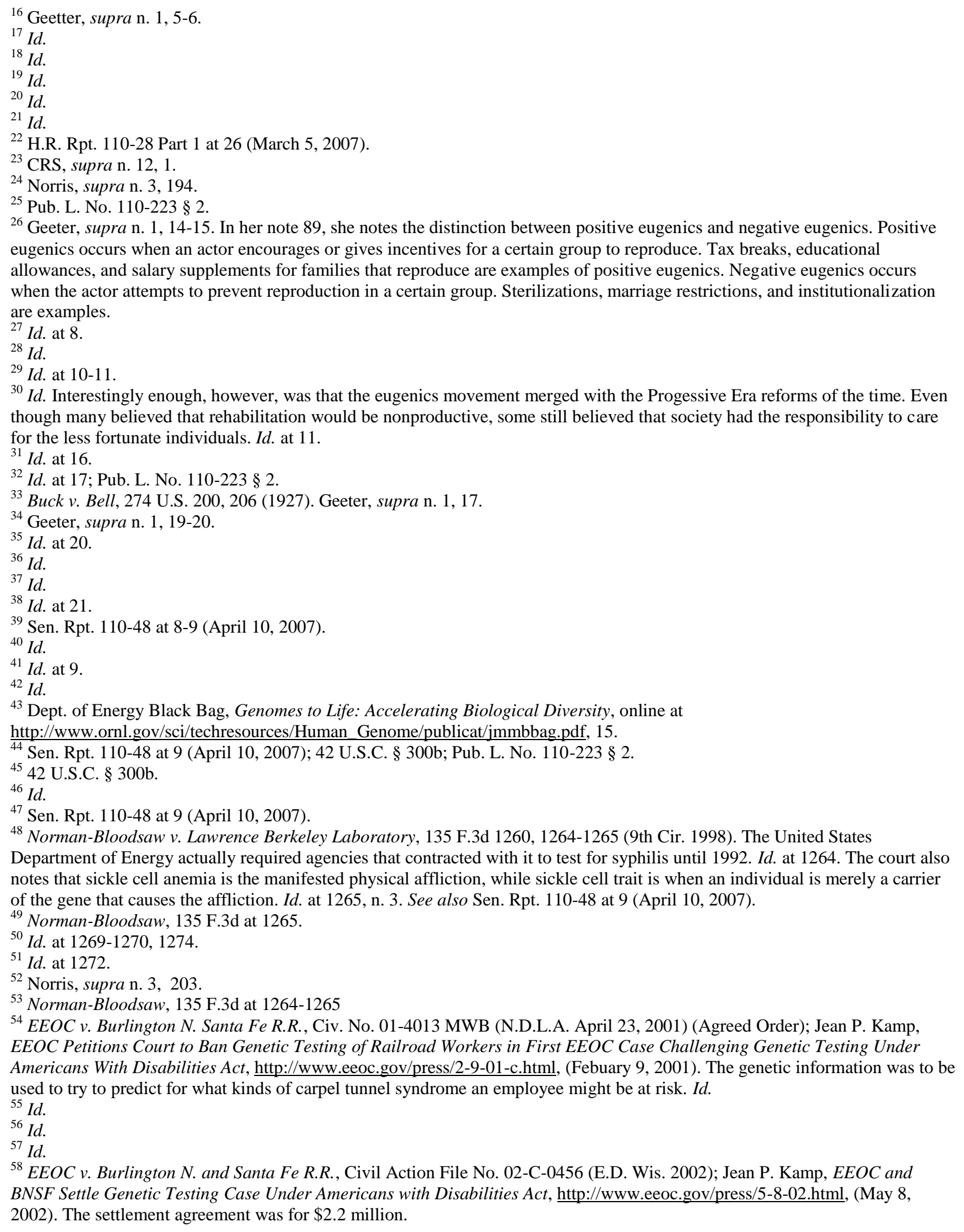




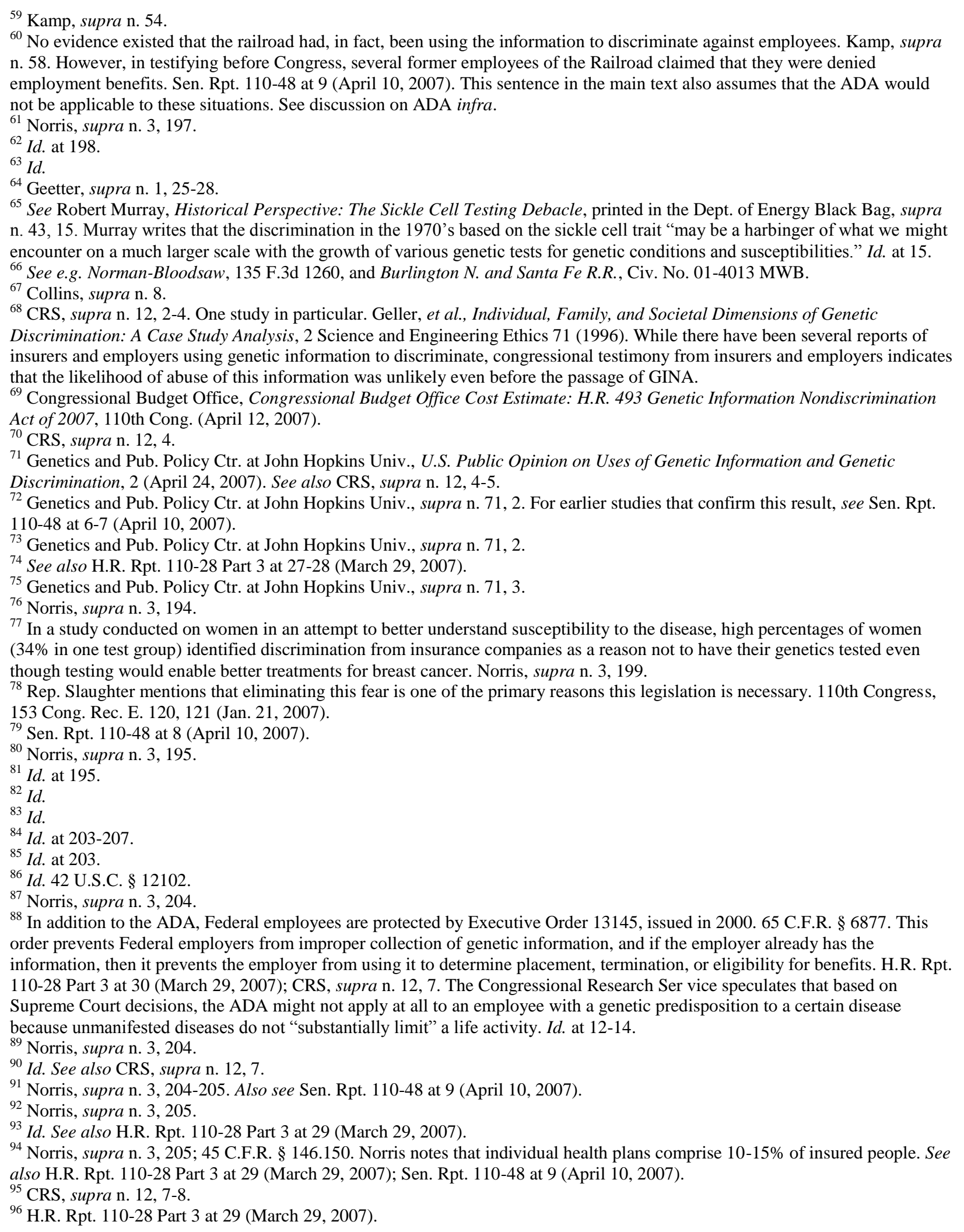


${ }^{97} I d$.

${ }^{98} I d$. The regulations cannot affect employers, for instance. HIPAA does, however, require that any entity working with a

"covered" entity sign a contract promising to protect the privacy of the information. Id. While this affords some protection, it is contractual in nature and not statutory. See also Sen. Rpt. 110-48 at 10-11 (April 10, 2007).

${ }^{99}$ Norris, supra n. 3, 205.

${ }^{100}$ Medicare.gov, Medigap (Supplemental Insurance) Policies, http://www.medicare.gov/medigap/Default.asp (last updated March 27, 2008).

${ }^{101}$ Norris, supra n. 3, 205; 42 U.S.C. § 1395ss(s)(2)(A); 42 U.S.C. § 1395ss(s)(3)(A).

102 Norris, supra n. 3, 205-206.

${ }^{103}$ H.R. 2748, 104th Cong. (1995). See also H.R. Rpt. 110-28 Part 1 at 23 (March 5, 2007).

${ }^{104}$ Pub. L. No. 104-191. H.R. Rpt. 110-28 Part 1 at 23 (March 5, 2007). See also Sen. Rpt. 110-48 at 13 (April 10, 2007).

${ }^{105}$ In the 105th Congress, she introduced virtually the same act as she had in the 104th Congress. H.R. 306, 105th Cong. (1997).

However, in both the 106th and 107th Congresses, she introduced the Genetic Nondiscrimination in Health Insurance and

Employment Act, explicitly included protections in the employment context. H.R. 2457, 106th Cong. (1999); H.R. 602, 107th

Cong. (2001); See also H.R. Rpt. 110-28 Part 1 at 23 (March 5, 2007).

${ }^{106}$ H.R. Rpt. 110-28 Part 1 at 23 (March 5, 2007).

${ }^{107}$ Sen. 1053, 108th Cong. (2003). See also Sen. Rpt. 110-48 at 15 (April 10, 2007).

${ }^{108}$ H.R. Rpt. 110-28 Part 1 at 23 (March 5, 2007).

${ }^{109}$ Sen. 306, 109th Cong. (2005). See also Sen. Rpt. 110-48 at 15 (April 10, 2007).

${ }^{110}$ H.R. Rpt. 110-28 Part 1 at 24 (March 5, 2007).

${ }^{111}$ H.R. 493, 110th Cong. (2007). During this Congress, Senator Snowe again introduced a bill. Sen. 386, 110th Cong. (2007).

The final bill to pass both houses is more similar to the House bill, but with certain amendments by Snowe (see the Snowe Amendment, Sen. Amendment No. 4573).

${ }^{112}$ H.R. Rpt. 110-28 Part 1 at 24 (March 5, 2007).

${ }^{113}$ Representatives Flake, Paul, and Royce were the only dissenters. 153 Cong. Rec. H. 4108.

${ }^{114}$ CRS, supra n. 12, 21. This is Senate bill 358.

${ }^{115}$ Representative Paul was the lone dissenter. 154 Cong Rec H 2961.

${ }^{116}$ National Human Genome Research Institute, President Signs H.R. 493, the Genetic Nondiscrimination Act of 2008, http://www.whitehouse.gov/news/releases/2008/05/print/20080521-7.html.

${ }^{117}$ Pub. L. No. 110-233.

11829 U.S.C. $\S 1181$.

${ }^{119}$ Pub. L. No. 110-233 $§ 101(a)$ and 102(a).

12029 U.S.C. $\$ 1182(a)$.

${ }^{121}$ Pub. L. No. 110-233 § 102(b) and 104(a).

${ }^{122}$ Pub. L. No. 110-233 §§ 101(b), 102(a), 102(b), 103(b), and 104(b).

${ }^{123}$ Pub. L. No. 110-233 §§ 101(b), 102(a), 102(b), 103(b), and 104(b). GINA, though, allows a health professional to request a patient to undergo a genetic test.

${ }^{124}$ Pub. L. No. 110-233 §§ 101(b), 102(a), 102(b), 103(b), and 104(b).

${ }^{125} \mathrm{Id}$.

${ }^{126}$ GINA does not indicate what these purposes might be, but this loophole in the law allows insurers to obtain genetic information, as long as it is not acquired for the purposes of underwriting. One case might be, for instance, when a policy insures more that one person in a family and one member of the family manifests a disease. The family member's disease is considered "genetic information" under the act. The insurer is able to obtain the information about the disease and may adjust premiums because it is a manifested disease. However, the insurer may not use the information to adjust premiums or change the eligibility status of other members of the family.

${ }^{127}$ Pub. L. No. 110-233 §§ 101(b), 102(a), 102(b), 103(b), and 104(b).

${ }^{128}$ Pub. L. No. 110-233 $§ \$ 101(b), 102(a), 102(b), 103(b)$, and 104(b).

${ }^{129}$ Pub. L. No. 110-233 §§ 101(d), 102(a), 103(d), and 104(b).

${ }^{130}$ See e.g. Pub. L. No. 110-223 § 101(c).

${ }^{131}$ Pub. L. No. 110-223 § 105(a).

${ }^{132}$ H.R. Rpt. 110-28 Part 1 at 25-26 (March 5, 2007).

${ }^{133}$ Pub. L. No. 110-223 §§ 101(e), 102(a), 102(b), and 103(e). H.R. Rpt. 110-28 Part 1 at 25-26 (March 5, 2007).

${ }_{134}$ Pub. L. No. 110-223 §§ 101(e), 102(a), 102(b), and 103(e). H.R. Rpt. 110-28 Part 1 at 25-26 (March 5, 2007).

${ }^{135}$ H.R. Rpt. 110-28 Part 1 at 33 (March 5, 2007). 29 U.S.C. $§ 1132(a)$.

${ }^{136}$ Pub. L. No. 110-223 § 105(a). H.R. Rpt. 110-28 Part 1 at 26 (March 5, 2007).

${ }^{137}$ Pub. L. No. 110-223 §§ 101(f) and 102(d).

${ }^{138}$ H.R. Rpt. 110-28 Part 1 at 66 (March 5, 2007).

${ }^{139} I d$. at $66-67$. 
${ }^{140} I d$. at 26.

${ }^{141}$ Pub. L. No. $110-223 \S 201(2) .42$ U.S.C. $§ 2000$ e(f).

${ }^{142}$ Pub. L. No. 110-223 § 201(4)(A). Title II also includes the genetic information of fetuses and embryos in the same language as Title I. $I d$. at $\S 209$ (b).

${ }^{143}$ Pub. L. No. $110-223 \S 210$.

${ }^{144}$ Pub. L. No. 110-223 § 201(4)(B).

${ }^{145}$ Pub. L. No. $110-223 \S 202(a)$.

${ }^{146}$ Pub. L. No. $110-223 \S 202$ (b).

${ }^{147}$ Pub. L. No. $110-223 \$ 202$ (b).

${ }^{148}$ Pub. L. No. 110-223 § 202(b). 29 U.S.C. § 2613. The Family and Medical Leave Act of 1993 allows an employer to require certification upon a request for leave by an employee. In order to make this certification valid, an employee will likely have to disclose family medical information that would fall into the definition of "genetic information" as defined under GINA.

${ }^{149}$ Pub. L. No. 110-223 $§ 202$ (b). The DNA analysis exception only exists if the employer is a forensic laboratory or the analysis is to identify human remains. Even in these cases, the employer can only use it for limited purposes.

${ }^{150}$ Pub. L. No. 110-223 § 202(b). The statute points out that, for instance, the Secretary of Labor might promulgate regulations under the Occupational Safety and Health Act of 1970 restricting how and in what instances an employer can genetically monitor employees.

${ }^{151}$ Pub. L. No. 110-223 § 202(b). H.R. Rpt. 110-28 Part 1 at 37 (March 5, 2007).

${ }^{152}$ Pub. L. No. 110-223 § 203(a).

${ }^{153}$ Pub. L. No. 110-223 § 204(a).

${ }^{154}$ Pub. L. No. $110-223$ § 205(a).

${ }^{155}$ Pub. L. No. 110-223 § 206(a). 42 U.S.C. $\$ 12112(d)(3)(B)$.

156 Pub. L. No. $110-223 \$ 206($ b).

${ }^{157}$ Pub. L. No. 110-223 § 206(b). 45 C.F.R. $§ 46$. This is a regulation from the Department of Health and Human Services designed to protect human subjects when undertaking health sciences research.

${ }^{158}$ Pub. L. No. $110-223 \S 206($ b).

${ }^{159}$ Pub. L. No. 110-223 § 206(b).

${ }^{160}$ Pub. L. No. 110-223 § 207(a). Enforcement of GINA for Government employers, although the enforcement is similar, is governed under a different statute.

${ }^{161}$ H.R. Rpt. 110-28 Part 1 at 27 (March 5, 2007). 42 U.S.C. $§ 1981$ a provides that a successful plaintiff is entitled to punitive and compensatory damages if certain conditions exist.

162 Pub. L. No. 110-223 § 207.

${ }^{163}$ Pub. L. No. $110-223 \S 213$.

${ }^{164}$ H.R. Rpt. 110-28 Part 1 at 67 (March 5, 2007).

${ }^{165}$ H.R. Rpt. 110-28 Part 1 at 67-68 (March 5, 2007).

${ }^{166}$ H.R. Rpt. 110-28 Part 1 at 68 (March 5, 2007). 


\section{NOTES}

